\title{
Silicate diagenesis in deep-sea sediments from the Tonga forearc (SW Pacific): a strontium and Rare Earth Elements signature
}

\author{
Frédéric VITALI ${ }^{a *}$, Gérard BLANC ${ }^{\text {b }}$, Theofilos TOULKERIDIS ${ }^{\text {, }}$, Peter STILLE ${ }^{a}$ \\ a Centre de géochimie de la surface, UMR CNRS n 7517, Institut de géologie, 1, rue Blessig, \\ 67084 Strasbourg cedex, France \\ ${ }^{\mathrm{b}}$ Département de géologie et d'océanographie, UMR CNRS n 5805, université Bordeaux I, \\ avenue des facultés, 33405 Talence, France \\ ${ }^{\mathrm{c}}$ Colegio de Ciencias e Ingeniería, Universidad San Francisco de Quito, P.O. Box 17-12-841, \\ Círculo de Cumbayá, Quito, Ecuador
}

Received 28 July 1999; revised 12 January 2000; accepted 12 January 2000

\begin{abstract}
Sr} /{ }^{86} \mathrm{Sr}$ isotopic ratios, strontium and Rare Earth Element concentrations obtained on volcano-sedimentary rocks and separated clay mineral and zeolite fractions reveal a formation by pore water-volcanic rock interaction for most of the hydrous silicate minerals of the Site 841 ODP collected from the Tonga forearc. Unusual strontium concentrations and isotopic ratios recorded in the Miocene tuffs associated with specific REE patterns indicate that the formation of these hydrous silicates does not follow a simple burial diagenesis model, but was related to the cooling of intruding basaltic sills in the Miocene volcano-sedimentary series. Migration of strontium into the pore water in response to the heat flow induced the formation of Sr-bearing zeolites such as clinoptilolite, heulandite and chabazite. No evidence of any influence of a further thermal pulse in the Eocene rhyolitic tuffs could be found. As recorded by the chemistry of their clay mineral fraction, the rhyolitic tuffs developed a polyphasic diagenetic process, which might have been influenced by a possible circulation of a fluid into structurally weak areas. (C) 2000 Ifremer/CNRS/IRD/Éditions scientifiques et médicales Elsevier SAS
\end{abstract}

\section{Tonga / silicates / strontium / Rare Earth Elements / diagenesis / heat flow}

Résumé - Diagenèse des silicates des séries sédimentaires de l'avant-arc Tonga (Pacifique sud-ouest) : étude de la signature en strontium et en terres rares. Les concentrations en strontium et en terres rares, ainsi que les rapports isotopiques ${ }^{87} \mathrm{Sr} /{ }^{86} \mathrm{Sr}$ des roches volcano-sédimentaires et des fractions argileuses et zéolitiques indiquent que la plupart des silicates hydratés du site 841 ODP de l'avant-arc Tonga se sont formés par interaction entre les roches volcaniques et les eaux interstitielles. Les concentrations et rapports isotopiques en strontium inhabituels, enregistrés dans les tufs du Miocène associés à des profils de terres rares spécifiques, indiquent que la formation de ces silicates hydratés ne suit pas un modèle de simple diagenèse d'enfouissement Elle est en relation directe avec le refroidissement d'intrusions de sill basaltiques dans les séries volcano-sédimentaires du Miocène. La migration du strontium dans les fluides interstitiels, en réponse au flux de chaleur, a entrainé la formation de zéolites contenant du strontium, telles que les clinoptilolite, heulandite et chabazite. Dans les tufs rhyolitiques de l'Éocène, aucune influence d'un flux thermique n'a été détectée. La chimie de la fraction argileuse de ces tufs indique qu'ils ont subi une diagenèse polyphasée probablement influencée par la circulation d'un fluide à travers leurs failles. (C) 2000 Ifremer/CNRS/IRD/Éditions scientifiques et médicales Elsevier SAS

Tonga / silicates / strontium / terres rares / diagenèse / flux thermique

\footnotetext{
* Correspondence and reprints: Department of Earth Sciences, The University of Western Ontario, London, Ontario, N6A 5B7, Canada;
} fvitali@julian.uwo.ca

(C) 2000 Ifremer/CNRS/IRD/Éditions scientifiques et médicales Elsevier SAS

PII: S0399-1784(00)00129-8/FLA 


\section{INTRODUCTION}

During the cruise of leg 135 ODP, the Joïdes Resolution SV recovered intensively altered volcanogenic material from site 841 at the Tonga forearc. This studied site is located on the upper trench slope, at a water depth of $4810 \mathrm{~m}$, approximately $55 \mathrm{~km}$ west of the axis of the Tonga Trench and $60 \mathrm{~km}$ east of the crest of the Tonga Ridge, at $23^{\circ} 20.7^{\prime} \mathrm{S}, 175^{\circ} 17.9^{\prime} \mathrm{W}$ [40] (figure 1). The sedimentary sequence is $605 \mathrm{~m}$ thick and ranges in age from Middle Pleistocene to Late Eocene. This sequence consists predominantly of clay minerals, vitric siltstones, volcanic conglomerates and breccias, and volcanic sandstones (figure 2). Basaltic dikes and sills intrude Miocene sediments and appear to be part of one main intrusive episode [7]. Below $605 \mathrm{~m}$, a rhyolite volcanic complex occurs, being dated with an age of $44 \pm 2$ Ma [29]. The mineral content of the collected sample from the

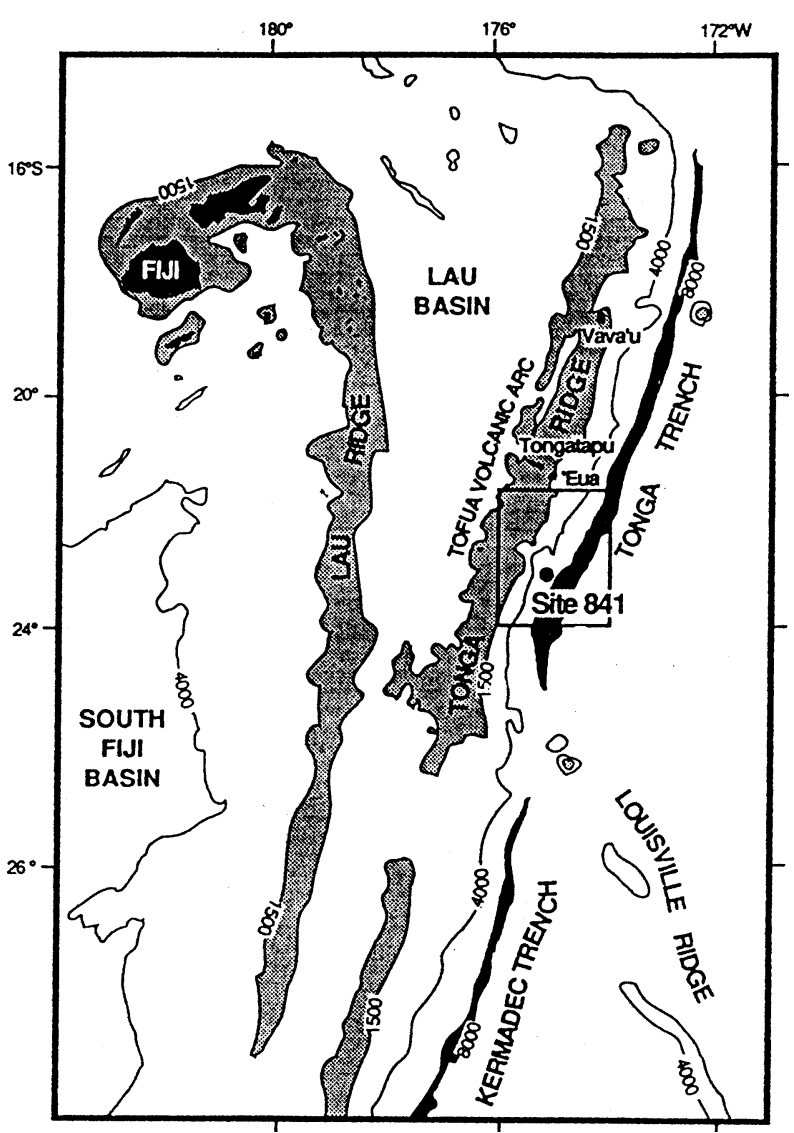

Figure 1. Location map of site 841 of the Tonga forearc, adapted from [32]. seafloor down to $605 \mathrm{mbsf}$ is dominated by clays and zeolites whereas the underlying highly rhyolitic volcanic complex is composed mainly of quartz and plagioclase, having also various types of clay minerals but no zeolites [48, 49] (figure 3). Based on the mineralogy of the clay minerals and zeolites, the volcano-sedimentary material has been previously subdivided into four zones: (a) the upper zone $(0-260$ mbsf), (b) the reactive zone (260-470 mbsf), which is characterized by the occurrence of numerous basaltic sills and of a large amount of zeolites and Fe-clays, (c) the lower zone (470-605 mbsf) and, finally, (d) the rhyolitic zone (605 mbsf to the base of the hole) [49] (figure 4).

In the present study, we attempt to correlate chemical and $\mathrm{Sr}$ isotopic patterns with the associated mineralogy and temperature of crystallization previously established using oxygen-isotopes in clays [50] in order to reconstruct the origin and the transformation of the sediments. Strontium and Rare Earth Elements (REE) distributions in sedimentary material appear to have the potential to be a powerful diagnostic tool in various geological settings. They are used as chemical and isotopic indicators of geological and oceanographic processes including assessment of crustal sources $[5,31,45,46]$, secular variation of seawater composition $[9,25,26,51]$, chemical sources of marine sediments $[20,30,35,36]$, hydrothermal activity $[1,2,46]$, and diagenesis $[3,4,10,22,37]$. In the Tonga forearc, elemental and $\mathrm{Sr}$ isotopic determinations and REE concentrations on whole rocks as well as on separated zeolite and clay mineral fractions should allow us (1) to obtain clues to the origin of the abundant hydrous silicate minerals (2) to evaluate the role of volcanic glass and pore water in the formation of diagenetic minerals, (3) to determine the potential consequences of a temperature increase resulting from intrusion episodes for the chemical content and the isotopic ratios of the sedimentary sequence (4) and to retrace the evolution of the diagenetic processes with regard to the mineralogy determined in the site.

\section{MATERIALS AND METHODS}

Based on semi-quantitative mineralogical determinations of bulk sediment and clay-sized fraction [48, 


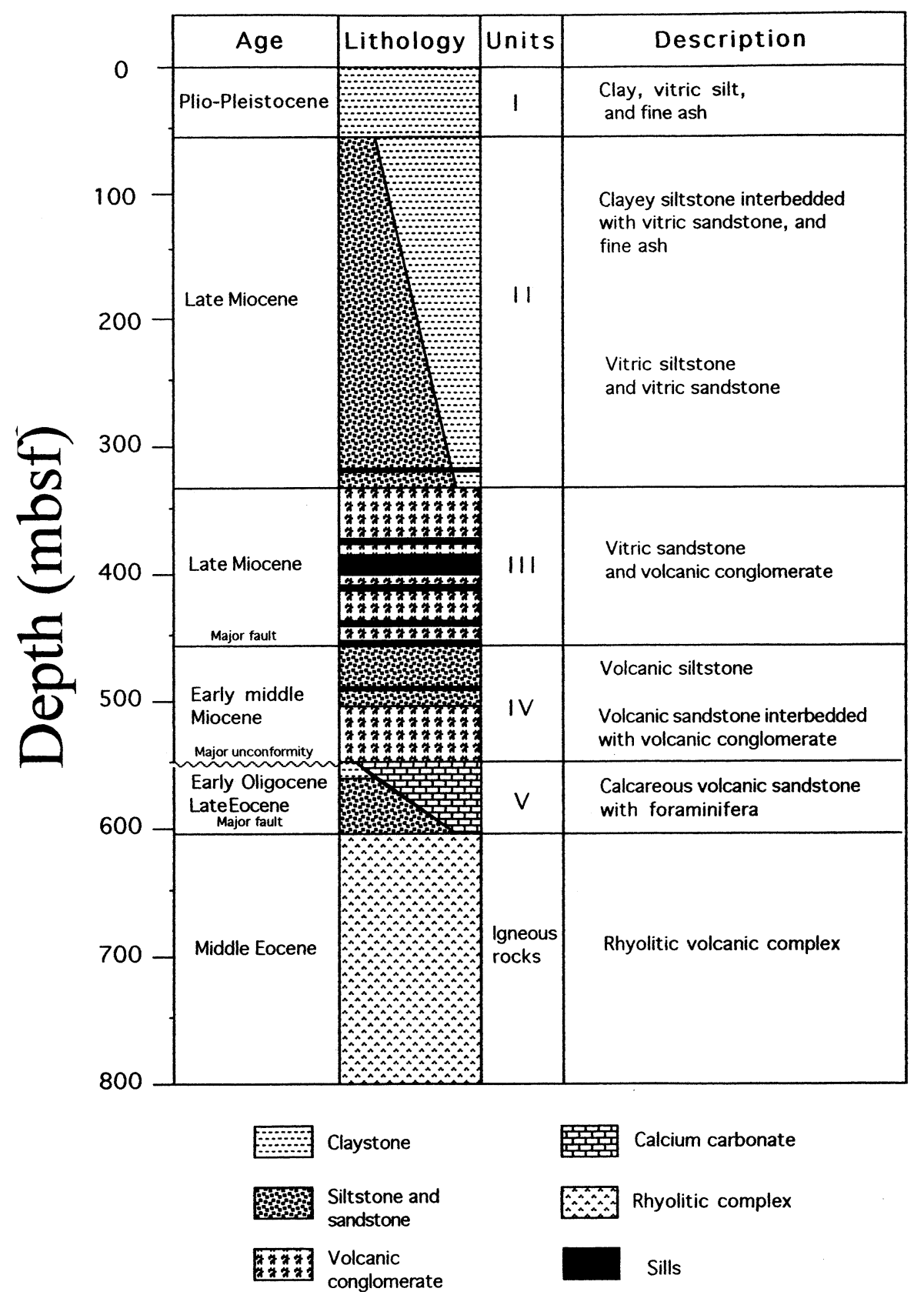

Figure 2. Schematic distribution of the lithostratigraphic units and of basaltic intrusions from site 841, from [48].

49], twelve samples representative of the entire sedimentary column have been selected for subsequent geochemical and isotopic studies. The clay fraction of the samples was separated by settling following the method described in Larqué and Weber [27] and Holtzapffel [24]. Clay types were determined by X-ray diffraction, scanning electron microscopy, and analyt- ical electron microscopy [47, 49] and the formation temperatures were estimated using measurements of their oxygen isotopes [50]. Unfortunately one whole rock sample (841B 54R2) was lost before the measurements were made. For that sample, chemical and isotopic results of the clay fraction only will be presented. 
Zeolites of the reactive zone have been previously observed by scanning electron microscopy in the grain scale of 20-63 $\mu \mathrm{m}$ [48]. Granulometric separation by sieving showed that zeolites were the only minerals which were detected in the $20-63 \mu \mathrm{m}$ fraction. X-ray diffraction of the 20-63 fraction of the 4 samples from the reactive zone indicated that sample
841B 15R1 occurring 296 mbsf was made up of $90 \%$ of analcime and $10 \%$ clinoptilolite, whereas analcime was the only zeolite in the three other zones. All samples were powdered in a carbon steel mill, dried at $110^{\circ} \mathrm{C}$ for $12 \mathrm{~h}$, and afterwards incinerated at $1000{ }^{\circ} \mathrm{C}$ for about three hours. Loss-on-ignition calculations resulted from the weight difference between

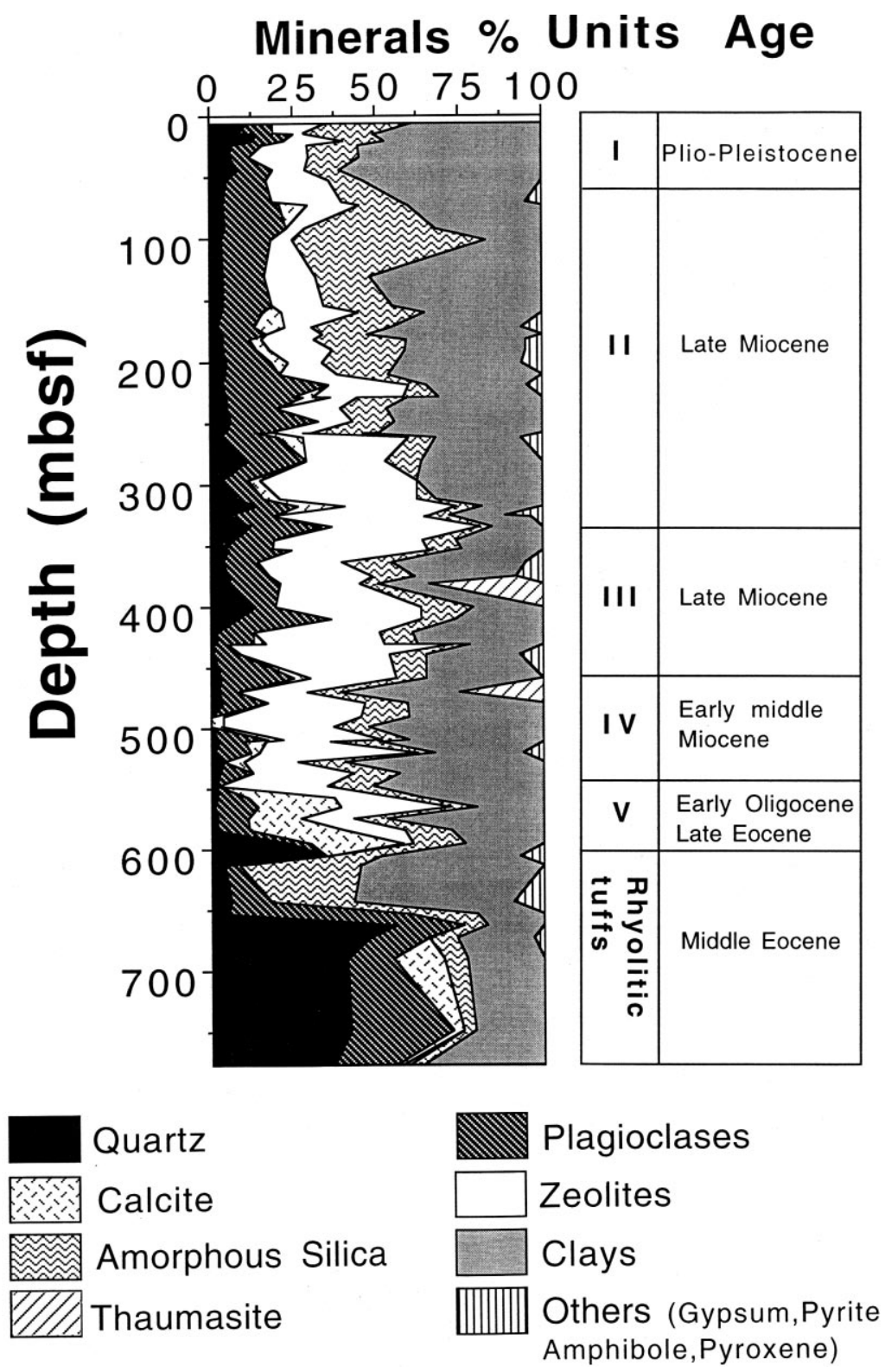

Figure 3. Mineral paragenesis according to depth. The weight percent of each mineral phase was determined by XRD and chemical analyses were calculated basing on a halite-free format, from [48]. Corresponding lithostratigraphic units were added on the right side of the figure. 


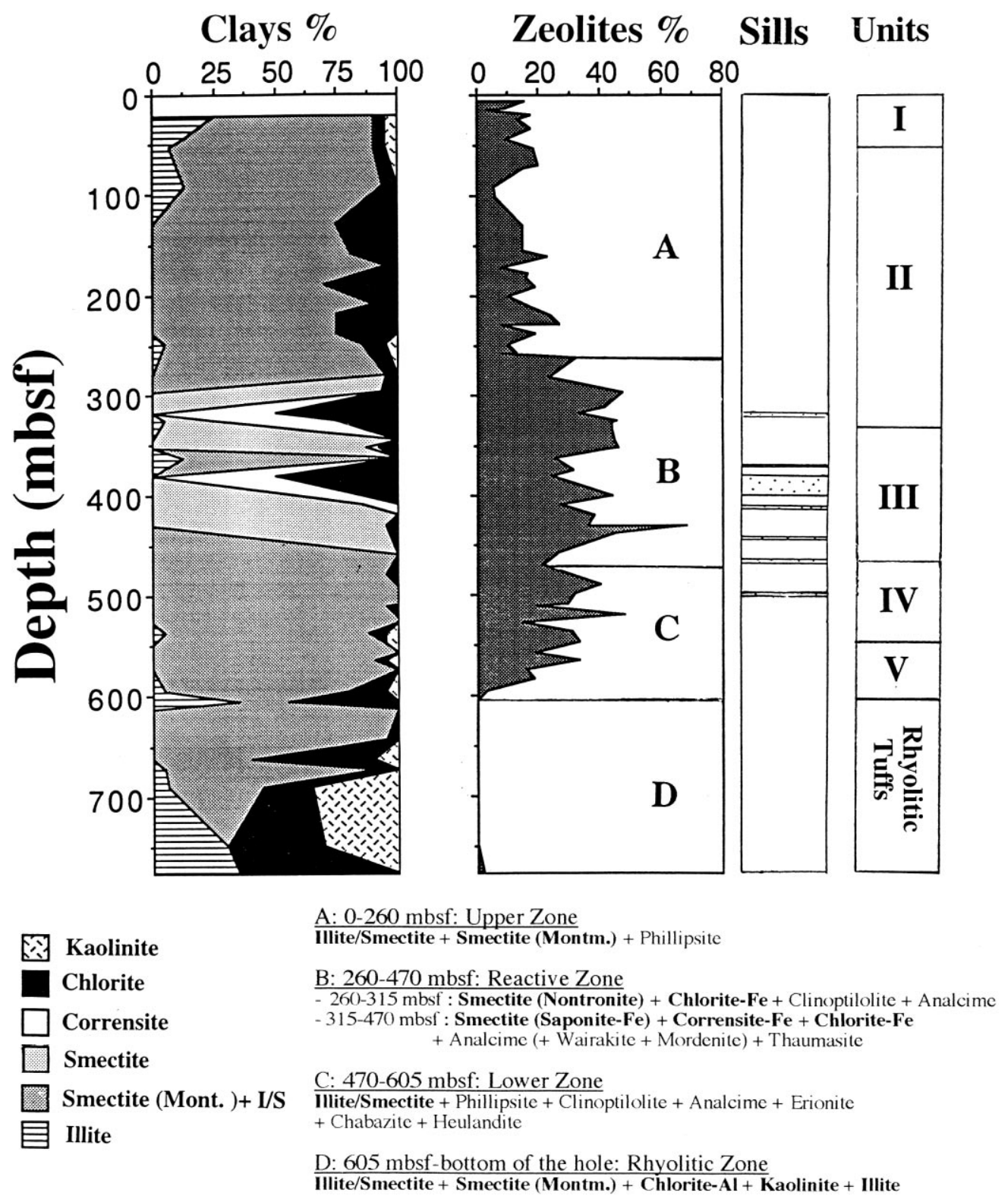

Figure 4. Mineralogical zonation based on the study of hydrous silicates, site 841 ODP, from [49]. Clay minerals are shown in bold format.

dried and calcinated samples. When available, sample splits of $140 \mathrm{mg}$ were fused for $20 \mathrm{~min}$ with $750 \mathrm{mg}$ of pure lithium tetraborate under inert Ar atmosphere in a crucible (Carbone Lorraine V25), and were dissolved as a molten fusion product in a glycerinehydrochloric acid solvent. Strontium and REE were determined by ICP-MS (Fison VG Isoplasma) at the Centre de Géochimie de la Surface in Strasbourg. Replicate analyses from samples and standards indi- cate that the accuracy of the REE and strontium determinations is within $5 \%$.

For isotopic determinations, sample dissolution was realised following Schaltegger et al. [42]. Prior to separation of strontium by cation exchange resins and to avoid interference with Fe during separation chemistry of $\mathrm{Sr}$, anionic exchange resins were used (AG1-X8 200-400 mesh, Biorad) with $9 \mathrm{~N} \mathrm{HCl}$ as 
eluent. Strontium isotopic analyses were performed in static mode on a VG Sector multicollector mass spectrometer. During the course of the study the value obtained for the ${ }^{87} \mathrm{Sr} /{ }^{86} \mathrm{Sr}$ isotopic ratio of the NBS 987 standard averaged $0.710266 \pm 0.000011(2 \sigma$ external, $\mathrm{n}=18$ ).

\section{RESULTS}

REE concentrations were obtained from whole rocks and clay fractions of all four zones, as well as from zeolites from the reactive zone (table I) and were normalised to chondritic values according to those of McLennan [30] (figure 5). The chondrite normalised REE patterns of whole rocks and clay mineral fractions from the upper $605 \mathrm{~m}$ range mostly between 10 and 20 times of the chondritic values. Clays from the upper and lower zone are enriched in light REE with regard to heavy REE (figures $5 b$ ). Zeolites from the reactive zone appear to have relatively flat REE patterns, with REE concentrations 10 times higher than those of the chondritic values (figure $5 c$ ). The chondrite-normalised REE patterns from the rhyolitic zone range mostly between 10 and 20 times the values of chondrites for the whole rocks (figure $5 a$ ) and between 10 and 50 times for the clays (figure $5 b$ ). In the rhyolitic tuffs, whole rocks and clay minerals present a heavy REE enrichment when compared to light REE. The europium anomaly is strongly negative with values between 0.44 and 0.55 which were calculated using the equation:

$$
\mathrm{Eu} / \mathrm{Eu}^{*}=\mathrm{Eu}_{\mathrm{N}} /\left(\mathrm{Sm}_{\mathrm{N}} \cdot \mathrm{Gd}_{\mathrm{N}}\right)^{1 / 2}[46]
$$

The clay fraction at $642.2 \mathrm{mbsf}$ (sample 841B 51R2) appears to have the lowest enrichment (10 times) when compared to chondritic values. This sample shows also a highly positive cerium anomaly of 1.43 calculated using the equation:

$\mathrm{Ce} / \mathrm{Ce}^{*}=3 \mathrm{Ce}_{\mathrm{N}} /\left(2 \mathrm{La}_{\mathrm{N}}+\mathrm{Nd}_{\mathrm{N}}\right)[8]$

Strontium concentrations of the whole rocks and of the clay minerals increase from $156 \mu \mathrm{g} \cdot \mathrm{g}^{-1}$ and $87 \mu \mathrm{g} \cdot \mathrm{g}^{-1}$ respectively at $52.5 \mathrm{mbsf}$ to $389 \mu \mathrm{g} \cdot \mathrm{g}^{-1}$ and $355 \mu \mathrm{g} \cdot \mathrm{g}^{-1}$ at $296.4 \mathrm{mbsf}$ (figure 6). They decrease to $73 \mu \mathrm{g} \cdot \mathrm{g}^{-1}$ and $70 \mu \mathrm{g} \cdot \mathrm{g}^{-1}$ respectively at $430.6 \mathrm{mbsf}$ and increase again in the carbonate-rich Eocene deposits to $310 \mu \mathrm{g} \cdot \mathrm{g}^{-1}$ and $173 \mu \mathrm{g} \cdot \mathrm{g}^{-1}$ at $557.4 \mathrm{mbsf}$. In the rhyolitic unit, strontium concen- trations range between 77 and $86.6 \mu \mathrm{g} \cdot \mathrm{g}^{-1}$ for the whole rocks and between 50 and $95 \mu \mathrm{g} \cdot \mathrm{g}^{-1}$ for the clays. The concentrations in zeolites from the reactive zone decrease from $349 \mu \mathrm{g} \cdot \mathrm{g}^{-1}$ at $296.4 \mathrm{mbsf}$ to 74 $\mu \mathrm{g} \cdot \mathrm{g}^{-1}$ at $352 \mathrm{mbsf}$ and then increase to $102 \mu \mathrm{g} \cdot \mathrm{g}^{-1}$ at 430.6 mbsf.

The ${ }^{87} \mathrm{Sr} /{ }^{86} \mathrm{Sr}$ isotopic ratios of the whole rocks vary from 0.70416 to 0.70672 (table II). The highest ${ }^{87} \mathrm{Sr}$ / ${ }^{86} \mathrm{Sr}$ isotopic ratios $(0.70672$ and 0.70667$)$ are located in the rhyolitic tuffs at $748.7 \mathrm{mbsf}$ and $776.2 \mathrm{mbsf}$ (table II and figure 7). The ${ }^{87} \mathrm{Sr} /{ }^{86} \mathrm{Sr}$ ratios of the clay fraction decrease from 0.708038 in the Plio-Pleistocene sediments (sample 841A 6H4, $52.5 \mathrm{mbsf}$ ), to 0.70567 at $352.4 \mathrm{mbsf}$ in the basaltic andesite tuffs and increase to 0.708272 at $776.2 \mathrm{mbsf}$ in the rhyolitic tuffs. However, at $674 \mathrm{mbsf}$, sample 54R2 shows a low isotopic value of $0.705400 .{ }^{87} \mathrm{Sr} /{ }^{86} \mathrm{Sr}$ ratios of zeolite decrease from 0.70535 at $296.4 \mathrm{mbsf}$ to 0.70429 at $352.4 \mathrm{mbsf}$, and increase afterwards to 0.70515 at $430.6 \mathrm{mbsf}$.

\section{DISCUSSION}

\subsection{Rare Earth Elements}

\subsection{1. $0-605 \mathrm{mbsf}$}

The first $605 \mathrm{~m}$ of the whole-rocks from site 841 show relatively flat chondrite-normalised REE patterns (figure 5). These REE patterns are similar when compared to turbidites from the fore-arcs located in the south and central Pacific Ocean [30, 31, 38, 39] (figure 8 ) and from andesite basaltic tuffs of Eua island [15]. According to McLennan [30], sedimentary rocks from an island arc have a similar REE pattern to the undifferentiated ones from the arc itself (similar to andesite), with low REE concentrations.

Whole rocks, clays, and zeolites from the first $605 \mathrm{~m}$ did not present any negative anomaly in cerium. The negative cerium anomaly is usually a clear record of an obvious seawater influence $[14,20,35]$. The absence of cerium anomaly has been previously observed in other volcano-sedimentary deposits from the Pacific Ocean, especially in the Mariana volcanic tuffs, which are Miocene in age [34]. In their investigation it was shown that the REE distribution in minerals (clays, zeolites), resulting from the interaction of seawater and volcanic rocks, did not always 
Table I. Rare Earth Element concentrations (in $\left.\mu \mathrm{g} \cdot \mathrm{g}^{-1}\right)$ of whole rocks and clays $(<2 \mu \mathrm{m})$ from the entire site and of zeolites from the reactive zone, site 841 ODP.

\begin{tabular}{|c|c|c|c|c|c|c|c|c|c|c|c|c|c|c|c|}
\hline $\mathbf{N}^{\circ} \mathrm{ODP}$ & Depth (mbsf) & $\mathrm{La}$ & $\mathrm{Ce}$ & $\operatorname{Pr}$ & $\mathrm{Nd}$ & $\mathrm{Sm}$ & $\mathrm{Eu}$ & $\mathrm{Gd}$ & $\mathrm{Tb}$ & Dy & Ho & $\mathrm{Er}$ & $\mathrm{Tm}$ & $\mathrm{Yb}$ & $\mathrm{Lu}$ \\
\hline \multicolumn{16}{|l|}{ Whole Rocks } \\
\hline 841 A $6 \mathrm{H4}$ & 52.5 & 9.35 & 20.44 & 3.04 & 13.00 & 3.57 & 1.03 & 3.76 & 0.7 & 4.37 & 1.06 & 3.12 & 0.43 & 3.19 & 0.47 \\
\hline 841B 19XI & 159.6 & 4.38 & 10.58 & 1.93 & 9.14 & 2.97 & 0.95 & 3.21 & 0.64 & 4.05 & 0.99 & 2.95 & 0.4 & 2.93 & 0.43 \\
\hline 841B 15R1 & 296.4 & 4.66 & 11.3 & 1.93 & 8.78 & 2.7 & 0.85 & 2.93 & 0.56 & 3.58 & 0.86 & 2.51 & 0.35 & 2.54 & 0.38 \\
\hline 841B 18R2 & 325.9 & 3.78 & 9.11 & 1.66 & 7.89 & 2.63 & 0.9 & 2.75 & 0.55 & 3.55 & 0.83 & 2.48 & 0.34 & 2.49 & 0.37 \\
\hline 841B 21R1 & 352.4 & 2.74 & 7.12 & 1.36 & 6.66 & 2.25 & 0.83 & 2.59 & 0.51 & 3.31 & 0.79 & 2.32 & 0.32 & 2.38 & 0.35 \\
\hline 841B 29R1 & 430.6 & 2.47 & 6.04 & 1.17 & 5.73 & 2.07 & 0.72 & 2.42 & 0.48 & 3.21 & 0.77 & 2.25 & 0.31 & 2.39 & 0.36 \\
\hline 841B 40R2 & 537 & 5.07 & 13.67 & 1.78 & 8.52 & 2.58 & 0.88 & 2.96 & 0.6 & 4.11 & 0.91 & 2.5 & 0.41 & 2.58 & 0.39 \\
\hline 841B 42R3 & 557.4 & 7.1 & 16.51 & 2.5 & 12.15 & 3.42 & 1.16 & 3.71 & 0.7 & 4.91 & 1.03 & 2.78 & 0.45 & 2.78 & 0.41 \\
\hline 841B 51R2 & 642.8 & 3.11 & 11.15 & 2.00 & 9.99 & 3.59 & 0.99 & 4.26 & 0.87 & 5.83 & 1.43 & 4.27 & 0.63 & 4.62 & 0.71 \\
\hline 841B 62R1 & 748.7 & 4.28 & 13.05 & 2.62 & 13.03 & 4.56 & 0.92 & 5.35 & 1.1 & 7.52 & 1.87 & 5.86 & 0.86 & 6.32 & 0.95 \\
\hline 841B 65RCC & 776.2 & 4.96 & 15.09 & 3.02 & 14.46 & 4.71 & 0.9 & 5.34 & 1.08 & 7.42 & 1.88 & 5.76 & 0.85 & 6.36 & 0.96 \\
\hline \multicolumn{16}{|l|}{ Clays } \\
\hline 841 A $6 \mathrm{H} 4$ & 52.5 & 7.45 & 16.73 & 2.5 & 10.4 & 2.93 & 0.78 & 2.96 & 0.56 & 3.52 & 0.83 & 2.44 & 0.34 & 2.52 & 0.38 \\
\hline 841B 19XI & 159.6 & 6.74 & 14.58 & 2.51 & 11.15 & 3.33 & 1.03 & 3.71 & 0.71 & 4.52 & 1.09 & 3.2 & 0.46 & 3.36 & 0.5 \\
\hline 841B 15R1 & 296.4 & 7.04 & 17.85 & 3.14 & 14.52 & 4.54 & 1.35 & 4.9 & 0.94 & 5.99 & 1.44 & 4.22 & 0.6 & 4.33 & 0.64 \\
\hline 841B 18R2 & 325.9 & 3.51 & 10.32 & 2.1 & 10.34 & 3.45 & 1.22 & 3.79 & 0.76 & 4.91 & 1.14 & 3.27 & 0.44 & 2.97 & 0.38 \\
\hline 841B 29R1 & 352.4 & 4.25 & 12.07 & 2.37 & 11.59 & 3.87 & 1.34 & 4.33 & 0.87 & 5.75 & 1.35 & 4.06 & 0.56 & 3.97 & 0.59 \\
\hline 841B 29R1 & 430.6 & 3.59 & 9.78 & 1.91 & 9.52 & 3.33 & 1.12 & 3.86 & 0.76 & 5.05 & 1.22 & 3.6 & 0.49 & 3.65 & 0.55 \\
\hline 841B 40R2 & 537 & 14.24 & 32.88 & 4.61 & 18.37 & 4.67 & 1.08 & 4.43 & 0.8 & 5.1 & 1.21 & 3.72 & 0.56 & 4.25 & 0.67 \\
\hline 841B 42R3 & 557.4 & 9.72 & 21.7 & 3.73 & 16.41 & 4.72 & 1.25 & 4.87 & 0.91 & 5.82 & 1.39 & 4.01 & 0.55 & 3.91 & 0.61 \\
\hline 841B 51R2 & 642.8 & 3.47 & 14.61 & 1.91 & 9.3 & 3.39 & 0.57 & 3.91 & 0.8 & 5.46 & 1.33 & 4.11 & 0.62 & 4.59 & 0.74 \\
\hline 841B 54R2 & 672.4 & 5.67 & 17.56 & 3.61 & 19.13 & 8.01 & 1.27 & 9.76 & 2.10 & 14.38 & 3.47 & 10.06 & 1.45 & 10.36 & 1.59 \\
\hline 841B 62R1 & 748.7 & 9.24 & 28.11 & 5.58 & 27.28 & 9.94 & 1.88 & 11.7 & 2.49 & 17.81 & 4.61 & 14.39 & 2.17 & 15.99 & 2.53 \\
\hline 841B 65RCC & 776.2 & 6.48 & 19.57 & 3.81 & 17.79 & 6.23 & 1.22 & 7.34 & 1.6 & 10.93 & 2.78 & 8.46 & 1.26 & 9.31 & 1.48 \\
\hline \multicolumn{16}{|l|}{ Zeoiltes } \\
\hline 841B 15R1 & 296.4 & 4.25 & 9.91 & 1.68 & 7.35 & 2.19 & 0.7 & 2.3 & 0.44 & 2.84 & 0.66 & 1.92 & 0.27 & 1.95 & 0.29 \\
\hline 841B 18R2 & 325.9 & 3.91 & 8.87 & 1.58 & 7.4 & 2.37 & 0.84 & 2.64 & 0.49 & 3.18 & 0.78 & 2.35 & 0.33 & 2.57 & 0.41 \\
\hline 841B 21R1 & 352.4 & 2.6 & 6.74 & 1.25 & 6.09 & 2.04 & 0.73 & 2.33 & 0.46 & 3.11 & 0.73 & 2.13 & 0.29 & 2.14 & 0.32 \\
\hline 841B 29R1 & 430.6 & 1.88 & 5.01 & 1.01 & 5.05 & 1.85 & 0.67 & 2.22 & 0.46 & 2.96 & 0.72 & 2.12 & 0.29 & 2.18 & 0.33 \\
\hline
\end{tabular}


a)

\section{Whole Rocks}

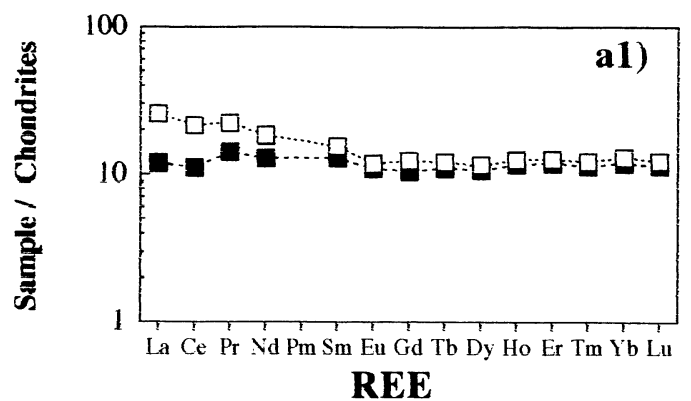

REE

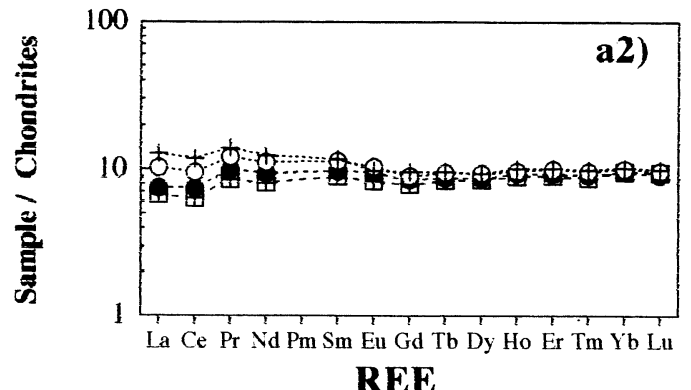

REE
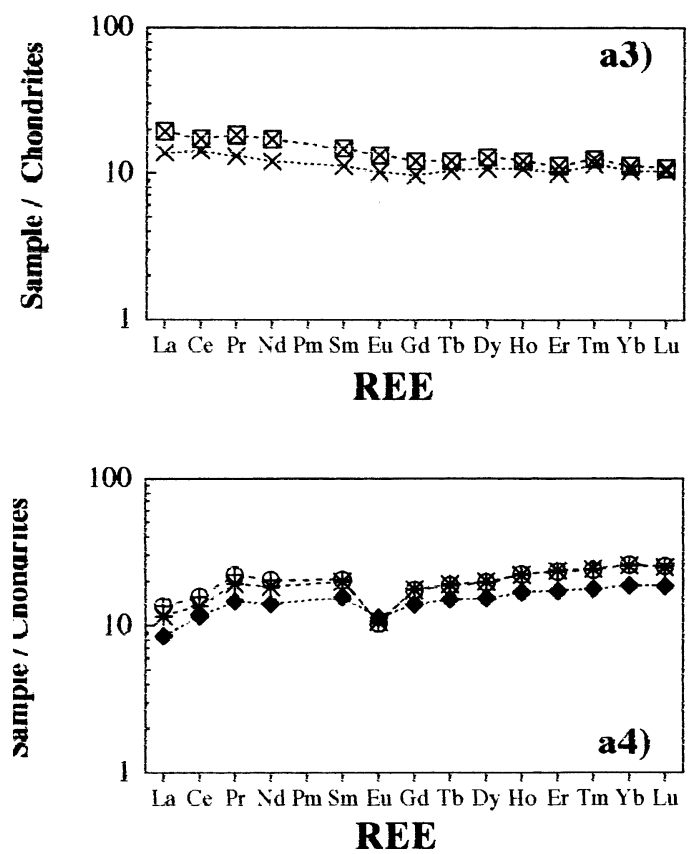

b)

Clays $(<2 \mu \mathrm{m})$
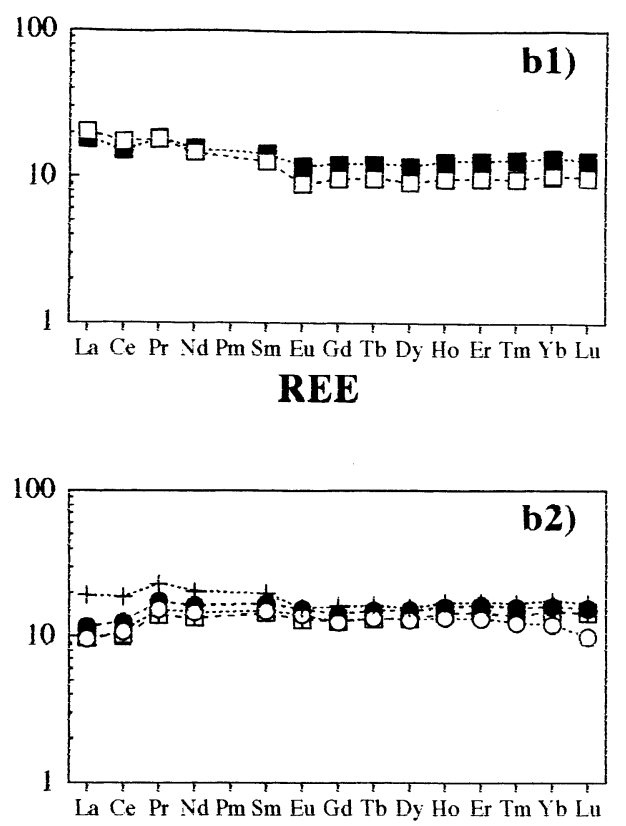

REE

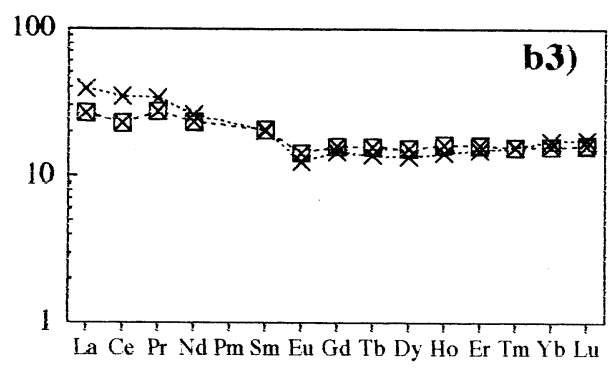

REE

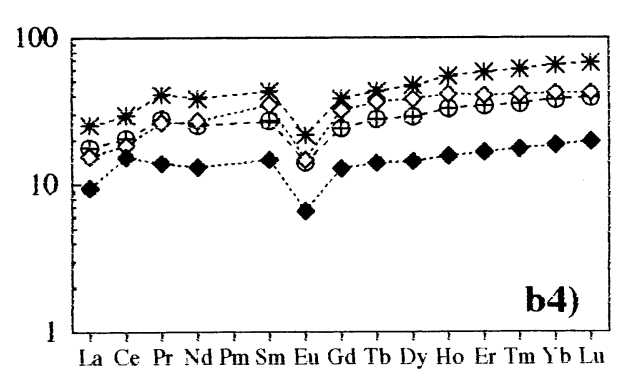

REF

Figure 5. Chondrite normalised REE patterns of: a) whole rocks, b) clays $(<2 \mu \mathrm{m})$, c) zeolites of the reactive zone $(1=$ upper zone, $2=$ reactive zone, $3=$ lower zone, $4=$ rhyolitic zone). 


\section{c) \\ Zeolites}
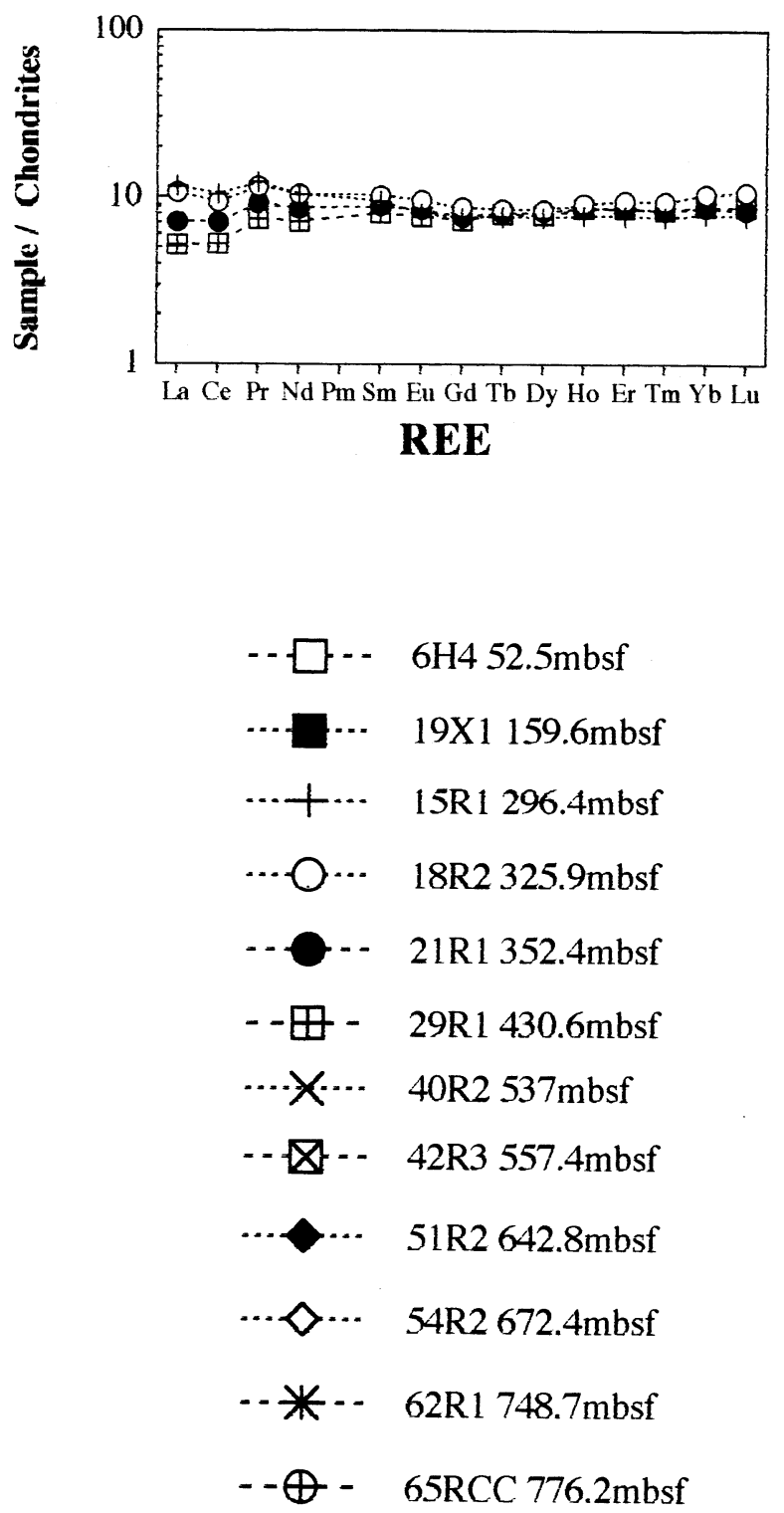

Fig. 5. (Continued)

record the REE characteristics of seawater. In many cases, secondary minerals inherited from the REE pattern of the source rocks and could reveal an increase of the REE concentration without any change in the REE patterns.
It is noticeable that clays and zeolites from the reactive zone show similar flat REE patterns to those of the whole rocks (figure 5c), and by extrapolation, also to those of fore-arc andesitic basalts. According to Desprairies and Bonnot-Courtois [13], the similarity between the REE pattern of authigenic minerals and of the initial rocks is a sign of the rapidity in crystallization of these minerals.

\subsubsection{The rhyolitic tuffs}

In the rhyolitic tuffs from the Tonga forearc, the negative $\mathrm{Eu}$ anomaly is related to magmatic fractionation. During magmatic fractionation, europium is incorporated in plagioclase. The fractionation of a large amount of plagioclase from a magma source (calc-alcaline basalt, arc tholeiite) might be able to perform such a negative $\mathrm{Eu}$ anomaly in a highly fractionated lava [30]. At $642.2 \mathrm{mbsf}$ (sample 841B $51 \mathrm{R} 2$ ), the clay fraction with the $\mathrm{Ce} / \mathrm{Ce}^{*}$ anomaly of 1.4 and the lowest concentration in REE compared to all other samples of the rhyolitic zone is located on a fault zone. The positive cerium anomaly and the decrease in REE concentrations of this sample might be a result of the immobilization of cerium into clays and of leaching of the trivalent REE and of europium by a possible fluid circulation into the faults of the rhyolitic tuffs.

\subsection{Strontium concentrations}

\subsection{1. $0-605 \mathrm{mbsf}$}

Strontium concentrations of the whole rocks decrease as low as $73.1 \mu \mathrm{g} \cdot \mathrm{g}^{-1}$ at $430.6 \mathrm{mbsf}$, in the centre of the reactive zone. Intrusion of the sill complex into water-saturated Miocene sediments would heat adjacent material and expel heated fluids enriched in $\mathrm{Sr}$ into surrounding porous media. Afterwards, this $\mathrm{Sr}$ has been incorporated in secondary minerals of the border zones. Actually, during diagenetic process, strontium tend to be released from the deposit rocks into pore water and incorporated in authigenic minerals [3]. Authigenic hydrous silicates such as clays, or zeolites from the heulandite group (heulandite, clinoptilolite) and chabazite, are able to incorporate high amounts of strontium [21, 28, 41]. SrO concentrations up to $8 \%$ in oxyde weight have been previously determined in Sr-heulandite. The low $\mathrm{Sr}$ concentrations $\left(\sim 50 \mu \mathrm{mol} \cdot \mathrm{L}^{-1}\right.$ on average $)$ in the 


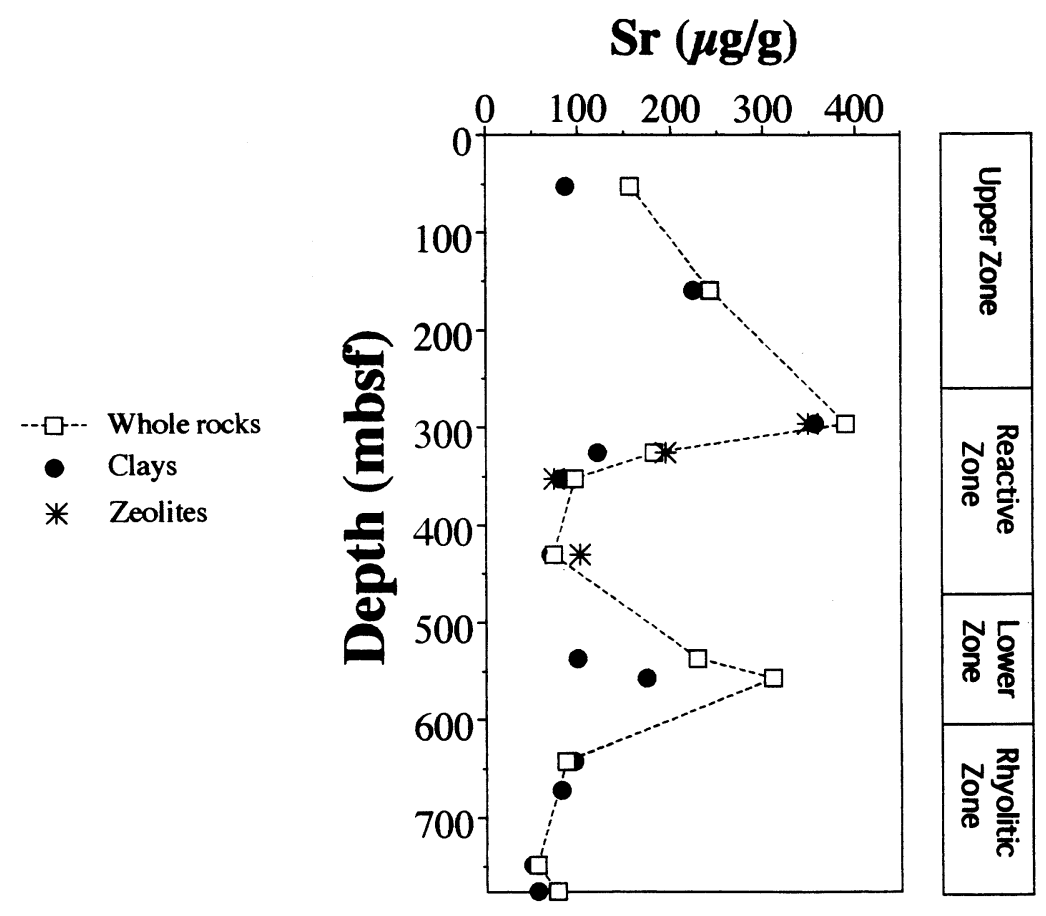

Figure 6. Strontium concentrations of whole rocks, clays, and zeolites from site 841 according to depth.

pore water present in the reactive zone argues for a recent crystallization of these minerals in response to the thermal pulse due to the cooling of the basaltic sills [6] (figure 9). Incorporation of strontium by authigenic minerals at the border of the thermal flux influence could explain the strontium concentrations which are as high as $349 \mu \mathrm{g} \cdot \mathrm{g}^{-1}$ measured for the zeolite fraction of sample 841 15R1 at $296.4 \mathrm{mbsf}$. Thus, authigenic clinoptilolite that constitute $5 \%$ of the sample [48] should have incorporated strontium expelled from the centre of the reactive zone. In the lower zone the same process of incorporation of $\mathrm{Sr}$ by authigenic minerals seems to occur, as it is recorded by $\mathrm{Sr}$ concentrations at $537 \mathrm{mbsf}$ (sample 841B 40R2) and 557.4 mbsf (sample 841B 42R3). In these samples, $\mathrm{Sr}$ concentration of the clay fraction is substantially lower $\left(70 \mu \mathrm{g} \cdot \mathrm{g}^{-1}\right.$ and $90 \mu \mathrm{g} \cdot \mathrm{g}^{-1}$, respectively) compared to those of the whole rocks (228 $\mu \mathrm{g} \cdot \mathrm{g}^{-1}$ and $310 \mu \mathrm{g} \cdot \mathrm{g}^{-1}$, respectively). Thus here, strontium is mainly incorporated in other phases rather than in clay minerals. Isolated zeolite fractions from the lower zone were not available but we might postulate that beside calcite, zeolites of this zone such as chabazite and heulandite seem to be the most probable Sr-bearing minerals. Zeolite minerals might have incorporated strontium released by the carbonates from unit $\mathrm{V}$. This may explain the high strontium concentration of the whole rocks at $537 \mathrm{mbsf}$, despite the poor content of calcite in that sample. In unit $\mathrm{V}$ at $557.4 \mathrm{mbsf}$, the high amount of calcite due to the high carbonate content seems to be the main factor inducing the high strontium concentration.

\subsubsection{The rhyolitic tuffs}

Strontium concentrations as low as $55.2 \mu \mathrm{g} \cdot \mathrm{g}^{-1}$ were determined in rhyolitic tuffs. Dissolution or albitisation of abundant plagioclases in the rhyolites during diagenetic processes most probably have released strontium into pore fluids and thus increased the $\mathrm{Sr}$ pore water concentrations, which is observed at the base of the hole [6] (figure 9).

\subsection{Strontium isotopes}

Previous ${ }^{87} \mathrm{Sr} /{ }^{86} \mathrm{Sr}$ isotopic determinations on basaltic andesites and rhyolites from the Tonga area and of related volcanic zones showed that Saipan rhyolites (Mariana Arc), Upper Eocene in age yield ${ }^{87} \mathrm{Sr} /{ }^{86} \mathrm{Sr}$ ratios varying between 0.70390 and 0.70439 [33], 
whereas ${ }^{87} \mathrm{Sr} /{ }^{86} \mathrm{Sr}$ ratios from Tonga basaltic andesites varied between 0.7036 and 0.7043 [16, 17]. These values are close to those obtained on young volcanic rocks (andesites, rhyolites) and usually of $0.704+1-$ $0.002[18,19,44]$. Isotopic ${ }^{87} \mathrm{Sr} /{ }^{86} \mathrm{Sr}$ ratios of volcanosedimentary samples from site 841 vary between 0.70416 and 0.70672 (table II, figure 7). Such values are not far from those of the volcanic pole $(0.704)$. Therefore, ${ }^{87} \mathrm{Sr} /{ }^{86} \mathrm{Sr}$ deviation from site 841 sediments compared to values determined on fresh basaltic andesites and rhyolites could be due to the influence ${ }^{87} \mathrm{Sr} /{ }^{86} \mathrm{Sr}$ variations with depth from the clays and zeolite minerals.

\subsection{1. $0-605 \mathrm{mbsf}$}

The ${ }^{87} \mathrm{Sr} /{ }^{86} \mathrm{Sr}$ ratios of the clay minerals from the first $605 \mathrm{~m}$ of the hole 841 are intermediate between the $\mathrm{Sr}$ isotopic ratio of the whole rock (and by extrapolation of an average and young volcanic rock) and of those of seawater contemporaneous to sediment deposition (figure 7). Strontium isotopic composition of the present-day ocean is homogeneous with a ${ }^{87} \mathrm{Sr} /{ }^{86} \mathrm{Sr}$ ratio of 0.709178) [9]. This homogeneity is due to the long residence time of $\mathrm{Sr}$ in oceans $\left(5 \times 10^{6}\right.$ years $)$ with respect to its mixing time (about $10^{3}$ years) [18]. However, the isotopic composition of seawater has changed with time and was close to 0.70890 during the Upper Miocene, 0.70820 during the Lower Miocene, 0.70800 during Oligocene and 0.70770 during the Eocene [25]. The ${ }^{87} \mathrm{Sr} /{ }^{86} \mathrm{Sr}$ ratios from the clay fraction of the first $605 \mathrm{~m}$ suggest that during their formation, clays integrated both strontium released by volcanic material as well as strontium of seawater. Clay minerals from the upper and lower zones (mont-

Table II. ${ }^{87} \mathrm{Sr} /{ }^{86} \mathrm{Sr}$ ratios and $\mathrm{Sr}$ concentrations (in $\left.\mu \mathrm{g} \cdot \mathrm{g}^{-1}\right)$ of whole rocks and clay $(<2 \mu \mathrm{m})$ from the entire site and of zeolites from the reactive zone, site 841 ODP.

\begin{tabular}{|c|c|c|c|c|}
\hline $\mathbf{N}^{\circ}$ ODP & Depth (mbsf) & ${ }^{87} \mathrm{Sr} /{ }^{86} \mathrm{Sr}$ & Precision & $\operatorname{Sr}(\mu \mathrm{g} / \mathrm{g})$ \\
\hline \multicolumn{5}{|l|}{ Whole Rocks } \\
\hline 841 A $6 \mathrm{H4}$ & 52.5 & 0.706061 & $+/-0.000010$ & 156.43 \\
\hline 841B 19XI & 159.6 & 0.704826 & $+/-0.000007$ & 242.78 \\
\hline 841B 15R1 & 296.4 & 0.705433 & $+/-0.000006$ & 389.42 \\
\hline 841B 18R2 & 325.9 & 0.705048 & $+/-0.000007$ & 181.35 \\
\hline 841B 21R1 & 352.4 & 0.70416 & $+/-0.000005$ & 96.33 \\
\hline 841B 29R1 & 430.6 & 0.70492 & $+/-0.000006$ & 73.15 \\
\hline 841B 40R2 & 537 & 0.706165 & $+/-0.000007$ & 227.96 \\
\hline 841B 42R3 & 557.4 & 0.70583 & $+/-0.000007$ & 310.23 \\
\hline 841B 51R2 & 642.8 & 0.704788 & $+/-0.000006$ & 86.67 \\
\hline 841B 62R1 & 748.7 & 0.706716 & $+/-0.000013$ & 55.25 \\
\hline 841B 65RCC & 776.2 & 0.706666 & $+/-0.000008$ & 77.01 \\
\hline \multicolumn{5}{|l|}{ Clays } \\
\hline 841 A $6 \mathrm{H} 4$ & 52.5 & 0.708038 & $+/-0.000006$ & 86.96 \\
\hline 841B 19XI & 159.6 & 0.707165 & $+/-0.000006$ & 223.78 \\
\hline 841B 15R1 & 296.4 & 0.705558 & $+/-0.000006$ & 355.77 \\
\hline 841B 18R2 & 325.9 & 0.705347 & $+/-0.000007$ & 120.61 \\
\hline 841B 21R1 & 352.4 & 0.705600 & $+/-0.000006$ & 80.61 \\
\hline 841B 29R1 & 430.6 & 0.706715 & $+/-0.000006$ & 69.92 \\
\hline 841B 40R2 & 537 & 0.706843 & $+/-0.000006$ & 99.20 \\
\hline $841 B$ 42R3 & 557.4 & 0.707024 & $+/-0.000009$ & 173.05 \\
\hline 841B 51R2 & 642.8 & 0.707354 & $+/-0.000007$ & 94.83 \\
\hline 841B 54R2 & 672.4 & 0.705400 & $+/-0.000007$ & 81.65 \\
\hline 841B 62R1 & 748.7 & 0.708269 & $+/-0.000007$ & 50.02 \\
\hline 841B 65Rcc & 776.2 & 0.708272 & $+/-0.000008$ & 55.55 \\
\hline \multicolumn{5}{|l|}{ Zeolites } \\
\hline 841B 15R1 & 296.4 & 0.705353 & $+/-0.000007$ & 348.66 \\
\hline 841B 18R2 & 325.9 & 0.704859 & $+/-0.000006$ & 193.64 \\
\hline 841B 21R1 & 352.4 & 0.704289 & $+/-0.000006$ & 74.18 \\
\hline 841B 29R1 & 430.6 & 0.705158 & $+/-0.000007$ & 102.10 \\
\hline
\end{tabular}




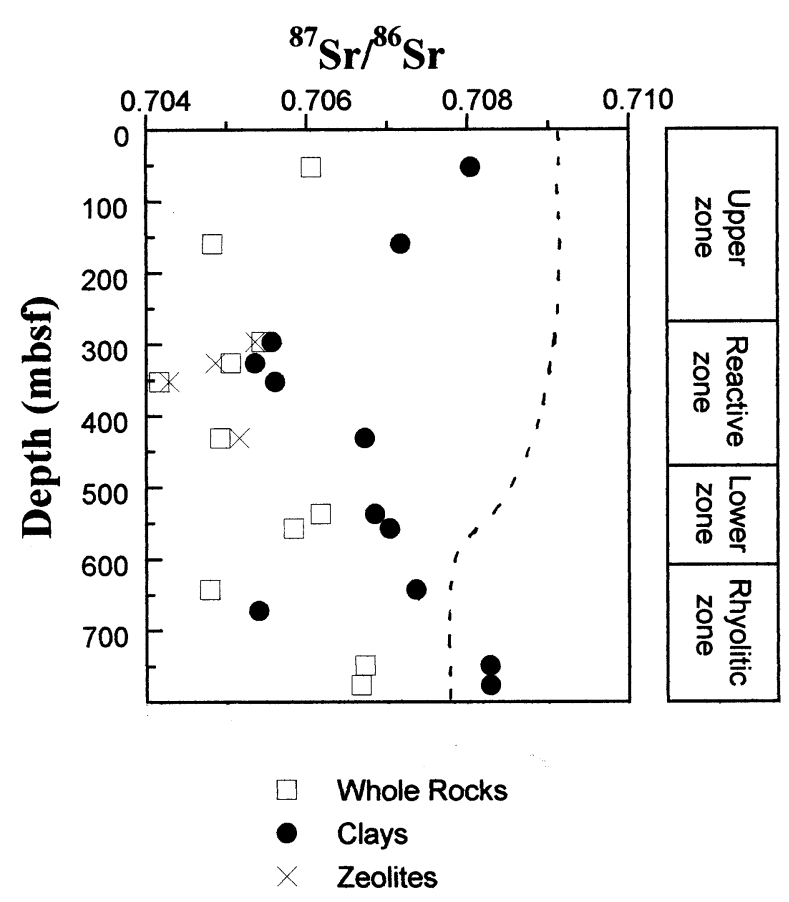

Figure 7. ${ }^{87} \mathrm{Sr} /{ }^{86} \mathrm{Sr}$ ratios of whole rocks, clays $(<2 \mu \mathrm{m})$ and zeolites from site 841 according to depth. Note that ${ }^{87} \mathrm{Sr} /{ }^{86} \mathrm{Sr}$ ratios of seawater corresponding to the age of the samples were also added.

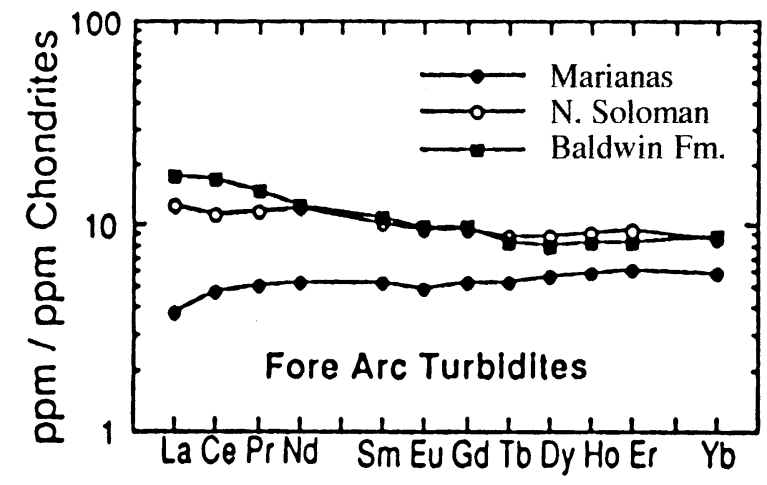

Figure 8. Chondrite normalized REE patterns of forearc turbidites from Pacific Ocean: Mariana, N. Solomon, and Baldwin Formation (Baldwin district, New South Wales, Australia) from [30].

morillonites and interlayers illite/montmorillonite) show ${ }^{87} \mathrm{Sr} /{ }^{86} \mathrm{Sr}$ isotope ratios close to those of the contemporaneous seawater. Conversely, clay minerals (chlorite-Fe, corrensite and saponite-Fe) from the reactive zone have lower Sr-isotopic values, being close to those of the andesitic-basaltic pole. Such variations could be due to the nature of the clay phase and to their time of crystallization.

${ }^{87} \mathrm{Sr} /{ }^{86} \mathrm{Sr}$ ratios obtained for zeolites of the reactive zone follow the same trend as the ${ }^{87} \mathrm{Sr} /{ }^{86} \mathrm{Sr}$ ratios of clay minerals of this zone. This strengthened the hypothesis that both clays and zeolites were induced by the same phenomena, e.g. alteration of the volcanic material in response to the cooling of the intrusive sills into the Miocene tuffs. Such pore water-volcanic material interactions also depleted the ${ }^{87} \mathrm{Sr} /{ }^{86} \mathrm{Sr}$ ratios of pore water from the reactive zone to values between 0.705528 to 0.70536 [6] (figure 9). However, ${ }^{87} \mathrm{Sr} /{ }^{86} \mathrm{Sr}$ ratios of zeolites are closer to those of an average volcanic glass (0.704 approximately) than the clay minerals located at the same depth. Thus, unlike clay minerals, the seawater does not appear to have any influence on the final strontium isotopic composition of the zeolites. Such contrasting behaviour between clays and zeolites regarding their preferential incorporation of strontium has been previously reported in the south Pacific Ocean, between the Tuamotu Archipelago and the Marquises Islands [23]. In the case of the Tonga trench, SEM observation allowed us to identify direct growth of analcime crystals on volcanic glass (plate 1) [47]. This mineralogical observation added to the similitude of this mineral strontium concentration with the whole rocks, and the similitude of the ${ }^{87} \mathrm{Sr} /$ ${ }^{86} \mathrm{Sr}$ ratio of zeolites with that of a volcanic glass argue for an incorporation of elements in zeolites directly from the volcanic glass. This might be possible in the case of a fast crystallization of zeolite minerals from the reactive zone, which seems to be also recorded by the REE, and which independently has been proposed due to modelisation based on the pore water concentration of $\mathrm{Na}$ and $\mathrm{Cl}$ [6].

\subsubsection{The rhyolitic tuffs}

At 672.4 mbsf, montmorillonite constitutes exclusively the clay fraction. Montmorillonite shows a strontium isotopic ratio of 0.7054 , which may be a result of an early crystallization at a relatively high temperature, most probably caused during cooling of the rhyolitic tuffs. A crystallization temperature of around $100{ }^{\circ} \mathrm{C}$ which was obtained by oxygen isotopic measurements of the same clay sample confirms this assumption [47]. In the lower part of the rhyolitic tuffs (samples 841B 62R1 at $748.7 \mathrm{mbsf}$ and 841B $65 \mathrm{RCC}$ at $776.2 \mathrm{mbsf}$ ), the ${ }^{87} \mathrm{Sr} /{ }^{86} \mathrm{Sr}$ ratios of the clay 
fraction are lower than those of present-day seawater but higher than those of Eocene seawater. The subsequent hypothesis might involve (a) an exchange with a more radiogenic meteoric water, or (b) a recharge of Eocene pore water with more recent seawater, or (c) a circulation into the rhyolitic tuffs of a fluid with a high ${ }^{87} \mathrm{Sr} /{ }^{86} \mathrm{Sr}$ ratio, or finally (d) a detrital origin, having a higher ${ }^{87} \mathrm{Sr} /{ }^{86} \mathrm{Sr}$ ratio, of which one part is the clay fraction.

(a) Rhyolitic tuffs from site 841 were formed in surface conditions, which implies contact with meteoric water, and subsided deeper than $5000 \mathrm{~m}[11,43]$. However, an exchange with more radiogenic meteoric water seems to be difficult to consider if the volcanic nature of the fields in this region and their mantle signatures $\quad\left({ }^{87} \mathrm{Sr} /{ }^{86} \mathrm{Sr}=0.703-0.704\right) \quad$ is $\quad$ being considered. (b and c) A seawater circulation or a circulation of an other fluid with higher ${ }^{87} \mathrm{Sr} /{ }^{86} \mathrm{Sr}$ ratio is possible because of the occurrence of structural weak areas such as faults in the rhyolitic tuffs $[12,40]$.

(d) Clay samples from rhyolitic tuffs are formed at $642.8 \mathrm{mbsf}$ (841B 51R1) and at $672 \mathrm{mbsf}$ (841B $54 \mathrm{R} 2)$ by interlayers $\mathrm{I} / \mathrm{S}(\mathrm{S}>70 \%)$ or by montmorillonites. The two deepest samples (841B 62R1 at 748.7 mbsf and 841B 65RCC at $776.2 \mathrm{mbsf}$ ), of which isotopic ratios are higher $(0.70819$ and 0.70827 respectively), contain either chlorite, kaolinite and illite or chlorite associated with illite. Mineralogical observations [47, 49] and studies by Schöps and Herzig [43] on clays from the rhyolitic tuffs of site 841 seem to exclude the possibility of a detrital origin for the clay minerals. However, doubt remains on the origin of the Al-chlorite of samples at 748.7 mbsf and 776.2 mbsf.

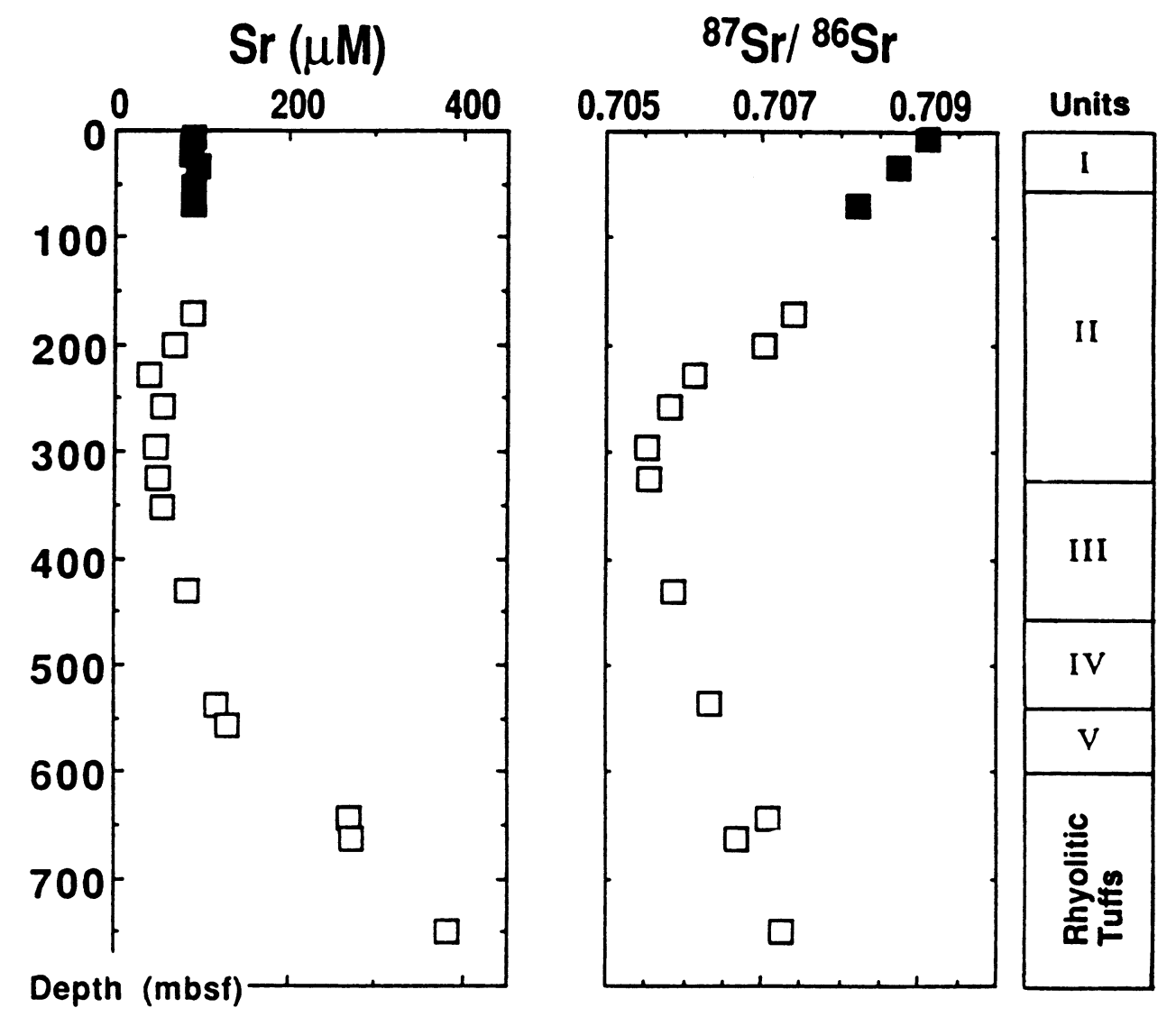

Figure 9. Concentration-depth profiles for $\mathrm{Sr}$ and ${ }^{87} \mathrm{Sr} /{ }^{86} \mathrm{Sr}$ of pore waters, site 841, from [6]. 


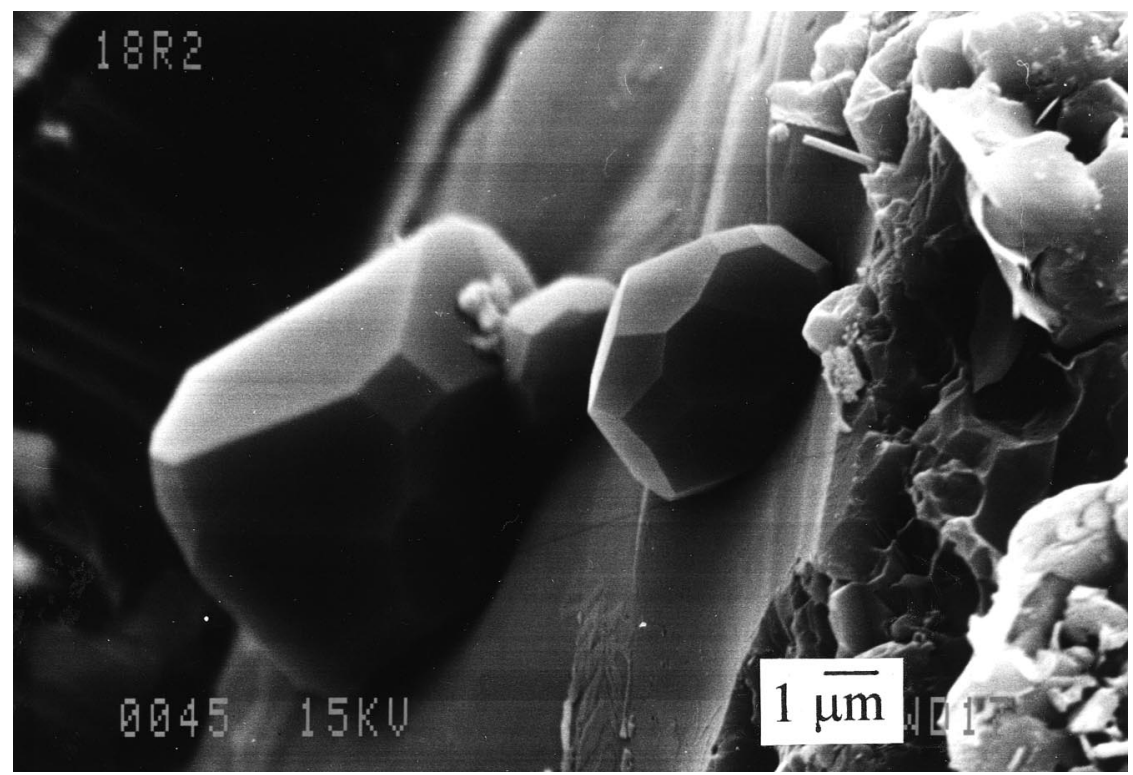

Plate 1. Scanning electron microscope observation of direct growth of analcime crystals on volcanic glass (sample 841B 18R2, 325.9 mbsf).

\section{CONCLUSIONS}

The rare earth elements and strontium record of the whole rocks and separated silicate fractions from site 841 of the Tonga forearc indicate that clay and zeolite formation result from the interaction between pore water and andesite basaltic or rhyolitic volcanic rocks. The similitude between strontium isotopic ratios of the clays and zeolites in the reactive zone argue for the same processes of formation of these minerals e.g. the cooling of basaltic sills in the centre of the sedimentary column. Normalised REE profiles and strontium isotopic ratios of clays and zeolites are almost similar to those of the volcanic glass indicating a fast crystallization of the secondary minerals located in the reactive zone. In the border zones, elements released by the recrystallization of calcite and by the extensive alteration of the volcanic glass could be incorporated in clay minerals but also in Sr-bearing zeolites such as clinoptilolite, chabazite and heulandite. The chemical and isotopic variations inside the rhyolitic tuffs of Eocene age reflect an independent diagenetic process with regard to the first $605 \mathrm{~m}$ of the volcano-sedimentary rocks. ${ }^{87} \mathrm{Sr} /$ ${ }^{86} \mathrm{Sr}$ of clay minerals indicate a polyphased diagenetic process including a possible migration during one of these phases of a fluid in the structural weak part of the rhyolitic tuffs.

\section{Acknowledgements}

We would like to thank ODP and the technical staff from the Centre de geochimie de la surface in Strasbourg. We acknowledge thoughtful reviews of the manuscript by the two anonymous reviewers. This research was supported by the French Committee of Marine Geosciences from INSU-CNRS.

\section{REFERENCES}

[1] Albarède F., Michard A., Minster J.F., Michard G., ${ }^{87} \mathrm{Sr} /{ }^{86} \mathrm{Sr}$ ratios in hydrothermal waters and deposits from the East Pacific Rise at $21^{\circ}$ N, Earth Planet. Sci. Lett. 55 (1981) 229-236.

[2] Anschutz P., Blanc G., Stille P., Origin of fluids and the evolution of the Atlantis II deep hydrothermal system, Red Sea: strontium isotope study, Geochim. Cosmochim. Acta 59 (1995) 4799-4808.

[3] Baker P.A., Gieskes J.M., Elderfield H., Diagenesis of carbonates in deep-sea sediments, Evidence from $\mathrm{Sr} / \mathrm{Ca}$ ratios and interstitial dissolved $\mathrm{Sr}^{2+}$ data, J. Sedim. Petrol. 52 (1982) $71-82$.

[4] Banner J.L., Application of the trace elements and isotope geochemistry of strontium to studies of carbonate diagenesis, Sedimentology 42 (1995) 805-824.

[5] Ben Othman D., White W.M., Patchett J., The geochemistry of marine sediments, island arc magma genesis, and crustmantle recycling, Earth Planet. Sci. Lett. 94 (1989) 1-21. 
[6] Blanc G., Vitali F., Stille P., Unusual diagenetic alteration of volcanoclastic sediments in the Tonga fore-arc: evidence from chemical and $\mathrm{Sr}$ isotopic composition of interstitial waters, Geochim. Cosmochim. Acta 59 (1995) 4633-4644.

[7] Bloomer S.H., Ewart A., Hergt J.M., Bryan W.B., Geochemistry and origin of igneous rocks from the outer forearc (Site 841), Proc. ODP Sci. Results 135 (1994) 625-646.

[8] Boust D., Les terres rares au cours de la diagenèse des sédiments abyssaux; Analogies avec un transuranien: L'Americium, PhD thesis, Univ. Caen, France, 1986.

[9] Capo R.C., De Paolo D.J., Seawater strontium isotopic variations from 2.5 million years ago to the present, Science 249 (1990) 386-400.

[10] Clauer N., Chaudhuri S., Clays in Crustal Environments: Isotope Dating and Tracing, Springer Verlag, Berlin, 1995.

[11] Clift P.D., Controls on the sedimentary and subsidence history of an active plate margin: an example from the Tonga Arc (Southwest Pacific), Proc. ODP Sci. Results 135 (1994) $173-188$

[12] Clift P.D., Bednarz U., Boe R., Rothwell R.G., Hodkinson R.A., Ledbetter J.K., Pratt C.E., Soakai S., Sedimentation on the Tonga Forearc related to arc rifting, subduction, erosion, and ridge collision: a synthesis of results from Sites 840 and 841, Proc. ODP Sci. Results 135 (1994) 843-853.

[13] Desprairies A., Bonnot-Courtois C., Relation entre la composition des smectites d'altération sous-marine et leur cortège de terres rares, Earth Planet. Sci. Lett. 48 (1980) 124-130.

[14] Elderfield H., Greaves M.J., The rare earth elements in seawater, Nature 296 (1982) 214-219.

[15] Ewart A., Bryan W.B., Petrography and geochemistry of the igneous rocks from Eua, Tonga Islands, Geol. Soc. Am. Bull. 83 (1972) 3281-3298.

[16] Ewart A., Hawkesworth C.J., The Pleistocene-Recent TongaKermadec Arc Lavas: interpretation of new isotopic and Rare Earth data in terms of a depleted mantle source model, J. Petrol. 28 (1987) 495-530.

[17] Ewart A., Brothers R.N., Mateen A., An outline of the geology and geochemistry, and the possible petrogenetic evolution of the volcanic rocks of the Tonga-Kermadec-New Zealand Island Arc, J. Volcanol. Geotherm. Res. 2 (1977) 205-250.

[18] Faure G., Principles of Isotope Geology, Wiley, New York, 1986.

[19] Faure G., Principles and Applications of Inorganic Geochemistry, MacMillan, New York, 1991.

[20] Fleet A.J., Aqueous and sedimentary geochemistry of the Rare Earth Elements, in: Henderson P. (Ed.), Rare Earth Element Geochemistry, Developments in Geochemistry 2, 1984, pp. 343-373.

[21] Gottardi G., Galli E., Natural Zeolites, Springer Verlag, Berlin, 1986.

[22] Gundogdu M.N., Bonnot-Courtois C., Clauer N., Isotopic and chemical signatures of sedimentary smectite and diagenetic clinoptilolite of a lacustrine Neogene basin near Bigadic, western Turkey, Appl. Geochem. 4 (1989) 635-644.
[23] Hoffert M., Karpoff A.M., Clauer N., Schaaf A., Courtois C., Pautot G., Néoformations et altérations dans trois faciès volcanosédimentaires du Pacifique Sud, Oceanol. Acta 1 (1978) 187-202.

[24] Holtzapffel, T., Les minéraux argileux: préparation, analyse diffractométrique et détermination, Soc. Géol. Nord 12 (1985) 136.

[25] Koepnick R.B., Burke W.H., Denison R.E., Hetherington E.A., Nelson H.F., Otto J.B., Waite L.E., Construction of the seawater ${ }^{87} \mathrm{Sr} /{ }^{86} \mathrm{Sr}$ curve for the Cenozoic and Cretaceous: supporting data, Chem. Geol. 58 (1985) 55-81.

[26] Koepnick R.B., Denison R.E., Burke W.H., Hetherington E.A., Dahl D.A., Construction of the Triassic and Jurassic portion of the Phanerozoic curve of seawater ${ }^{87} \mathrm{Sr} /{ }^{86} \mathrm{Sr}$, Chem. Geol. 80 (1990) 327-349.

[27] Larqué, P., Weber, F., Techniques de préparation des minéraux argileux en vue de l'analyse par diffraction des rayons $\mathrm{X}$, Note Tech. Instit. Géol. Strasbourg, 1978, 33 p.

[28] Lucchetti, G., Massa, B., Penco, A.M., Strontian heulandite from Campegli (Eastern Ligurian Ophiolites, Italy), Neues Jahrb. Miner. Monatsh. (1982) 541-550.

[29] Mc Dougall I., Data Report: Dating of rhyolitic glass in the Tonga Forearc (Hole 841B), Proc. ODP Sci. Results 135 (1994) 923.

[30] Mc Lennan S.M., Rare Earth Elements in sedimentary rocks: influence of provenance and sedimentary processes, in: Lipin B.R., McKay G.A. (Eds.), Geochemistry and Mineralogy of Rare Earth Elements, Mineral. Soc. Am. 21, 1989, pp. 171200.

[31] Mc Lennan S.M., Taylor S.R., Mc Culloch M.T., Maynard J.B., Geochemical and Nd-Sr isotopic composition of deepsea turbidites: crustal evolution and plate tectonic associations, Geochim. Cosmochim. Acta 54 (1990) 2015-2050.

[32] McLeod C.J., Structure of the Outer Tonga Forearc at Site 841, Proc. ODP Sci. Results 135 (1994) 313-329.

[33] Meijer A., The origin of Low-K Rhyolites from the Mariana Frontal Arc, Contrib. Mineral. Petrol. 83 (1983) 45-51.

[34] Migidisov A.A., Miklishansky A.Z., Saveliev B.V., Bredanova N.V., Girin Y.P., Pavlutskaya V.I., Yakovlev Y.V., Neutron activation analysis of Rare Earth Elements and some other trace elements in volcanic ashes and pelagic clays, Deep Sea Drilling Project Leg 59, DSDP Init. Rep. 59 (1981) 653-668.

[35] Murray, R.W., Buchholtz Ten Brink, M.R., Jones, D.L., Gerlach, D.C., Russ, III G.P., Rare earth elements as indicators of different marine depositional environments in chert and shale, Geology 18 (1990) 268-271.

[36] Murray, R.W., Buchholtz Ten Brink, M.R., Brumsack, H.J., Gerlach, D.C., Russ, III G.P., Rare earth elements in Japan Sea sediments and diagenetic behavior of $\mathrm{Ce} / \mathrm{Ce}^{*}$, results from ODP Leg 127, Geochim. Cosmochim. Acta 55 (1991) 24532466.

[37] Murray, R.W., Buchholtz Ten Brink M.R., Gerlach, D.C., Russ, III G.P., Jones, D.L., Rare earth, major, and trace element composition of Monterey and DSDP chert and associated host sediment: Assessing the influence of chemical 
fractionation during diagenesis, Geochim. Cosmochim. Acta 56 (1992) 2657-2671.

[38] Nance W.B., Taylor S.R., Rare earth element patterns and crustal evolution, I. Australian post-Archean sedimentary rocks, Geochim. Cosmochim. Acta 40 (1976) 1539-1551.

[39] Nance W.B., Taylor S.R., Rare earth element patterns and crustal evolution, II. Archean sedimentary rocks from Kalgoorlie, Australia, Geochim. Cosmochim. Acta 41 (1977) $225-231$

[40] Parson, L., Hawkins, J., Allan, J., Shipboard Scientific Party, Proc. ODP, In. Rep. 135, 1992, 677 p.

[41] Passaglia E., The crystal chemistry of chabazites, Am. Miner. 55 (1970) 1278-1301.

[42] Schaltegger U., Stille P., Rais N., Piqué A., Clauer N., Nd and $\mathrm{Sr}$ isotopic dating of diagenesis and low-grade metamorphism of argillaceous sediments, Geochim. Cosmochim. Acta 58 (1994) 1471-1481.

[43] Schöps D., Herzig P.M., Hydrothermally altered felsic rocks of the Tonga Forearc, Proc. ODP. Sci. Results 135 (1994) $653-663$.

[44] Shaffer N.R., Faure G., Regional variation of $87 \mathrm{Sr} / 86 \mathrm{Sr}$ ratios and mineral compositions of sediment from the Ross Sea, Antarctica, Geol. Soc. Am. Bull. 87 (1976) 1491-1500.

[45] Taylor S.R., Mc Lennan S.M., The Continental Crust: Its Composition and Evolution, Blackwell, Oxford, 1985.
[46] Taylor, S.R., Mc Lennan, S.M., The significance of the Rare Earths in geochemistry and cosmochemistry, in: Handbook on the Physics and Chemistry of Rare Earths, Vol. 11, Gschneider, K.A. Jr., Eyring, L. (Eds.) Elsevier Science, Amsterdam, 1988, pp. 485-578.

[47] Vitali, F., Géochimie des séries volcano-sédimentaires et des eaux interstitielles du sud-ouest Pacifique (Exemple de la marge active Tonga), PhD thesis, Univ. Strasbourg I, France, 1996, 148 p.

[48] Vitali F., Blanc G., Larqué Ph., Zeolite distribution in volcaniclastic deep-sea sediments from the Tonga Trench margin (S.W. Pacific), Clays Clay Miner. 43 (1995) 92-104.

[49] Vitali F., Blanc G., Larqué Ph., Duplay J., Morvan G., Thermal diagenesis of clay minerals within volcanogenic material from the Tonga convergent margin, Mar. Geol. 157 (1999) $105-125$.

[50] Vitali F., Blanc G., Gauthier-Lafaye F., France-Lanord C., Formation temperatures of clays from the volcaniclastic series of Site 841 ODP: an oxygen isotopic record of a paleothermal flux into the Tonga forearc, Contrib. Mineral. Petrol. 134 (1999) 364-369.

[51] Wright J., Schrader H., Holser W.T., Paleoredox variations in ancient oceans recorded by rare earth elements in fossil apatite, Geochim. Cosmochim. Acta 51 (1987) 631644. 